\title{
Причини незадовільних результатів діагностики перитоніту на догоспітальному етапі
}

\author{
О.О. Біляєва' ', В.В. Крижевський', І.В. Кароль ${ }^{1,2}$ \\ 'Національний університет охорони здоров'я України імені П.Л. Шупика, Київ, Україна \\ 2Комунальне некомерційне підприємство «Броварська багатопрофільна клінічна лікарня», Бровари, Україна
}

Анотація. Мета: вивчення причин незадовільних результатів діагностики перитоніту на догоспітальному етапі. Об'єкт і методи дослідження. У дослідження включено 265 хворих на перитоніт різного генезу, що проліковані в 2020 р. в хірургічному відділенні Броварської багатопрофільної клінічної лікарні, з них 124 (46,8\%) жінки та 141 (53,2\%) чоловік. Результати. Після 24 год 3 моменту виникнення перших симптомів захворювання госпіталізували 87 (32,8\%) пацієнтів. 3 них у 49 (56,3\%) випадках відмічали місцевий, у 28 (32,2\%) - дифузний, у 7 (8,0\%) - розлитий, і у 3 (3,5\%) - загальний перитоніт. При пізній госпіталізації пацієнтів характер ексудату в черевній порожнині при перитоніті був серозним у 12 (13,8\%), серозно-фібринозним - в 19 (21,8\%) випадках, фібринозногнійним - в 11 (12,6\%), гнійним - в 39 (44,8\%), каловим - в 1 (1,2\%), геморагічним - в 3 (3,5\%) та жовчним - в 2 (2,3\%) випадках. Висновки. Найважливіша причина незадовільних результатів діагностики та лікування перитоніту 一 пізнє звернення за медичною допомогою, яке $\epsilon$ наслідком самолікування чи звертання до спеціалістів нетрадиційної медицини. Із 87 випадків пізньої госпіталізації пацієнтів із перитонітом у 64 (73,6\%) випадках причиною було самолікування, у 7 (8,0\%) — нетрадиційна медицина, в 16 (18,4\%) — помилки медичних працівників як на догоспітальному, так і на госпітальному етапах.

Ключові слова: перитоніт, ендогенна інтоксикація, поліорганна недостатність.

\section{Вступ}

На сьогодні перитоніт $є$ одним $з$ найтяжчих ускладнень гострих запальних захворювань органів черевної порожнини [1-5]. Незважаючи на розробку та впровадження нових методик в лікуванні хворих на перитоніт, ця проблема залишається складною та невирішеною. Летальність при розвитку синдрому поліорганної недостатності сягає 80-90\%. Причинами такої високої летальності $\epsilon$ пізн $є$ звернення за медичною допомогою, коли значно порушені життєво важливі функції організму, похилий вік хворих та наявність тяжкої супутньої патології, антибіотикорезистентність мікрофлори, що значно посилилася в останні роки [5-8].

Тяжким перебігом характеризується синдром ендогенної інтоксикації при перитоніті, який розвивається через кишкову недостатність. Внаслідок цього процесу змінюються якість та кількість кишкової мікрофлори, концентрація мікроорганізмів та токсинів у черевній порожнині та судинному руслі [9].

Однією з основних причин незадовільних результатів лікування хворих на перитоніт $\epsilon$ пізня госпіталізація. Важливою причиною виникнення тяжких та поширених форм перитоніту $\epsilon$ складність діагностики гострих хірургічних захворювань органів черевної порожнини, що ведуть до розвитку перитоніту, та невчасне звернення за медичною допомогою. Ще в 1974 р. В.Д. Федоров наголошував, що основною причиною затримки хірургічного втручання у хворих на гострий апендицит $\epsilon$ пізн $\epsilon$ звернення до лікаря [5].

Лікувальна тактика у хворих на гострі захворювання органів черевної порожнини залежить від характеру самого захворювання, проте їх диференційна діагностика буває дуже складною $[10,11]$. Проблема може ускладнитися пізнім зверненням пацієнта за медичною допомогою, коли основне захворювання прогресує, клінічна картина стирається і на перший план виходить клініка перитоніту.

Зарубіжні та вітчизняні хірурги приділяють велику увагу вивченню перитоніту. Важливим досягненням $\epsilon$ поглиблене вивчення етіології і патогенезу перитоніту, принципів інтенсивної терапії і хірургічного лікування. Але незважаючи на це, дані багатьох авторів та власні спостереження авторів свідчать про високу летальність при перитоніті і відсутність тенденції до її зниження. Причини такої високої летальності різні. До них можна віднести пізнє звернення за медичною допомогою, діагностичні помилки на догоспітальному етапі та в стаціонарі, тактичні по- милки під час операції і в післяопераційний період, пізню діагностику післяопераційних ускладнень та ін.

Враховуючи все вищезазначене, актуальність цієї теми не викликає сумнівів.

Мета дослідження: вивчення причин незадовільних результатів діагностики перитоніту на догоспітальному етапі.

\section{Об'єкт і методи дослідження}

Враховуючи діагностичні помилки лікарів у встановленні діагнозу «перитоніт» на догоспітальному етапі через неправильну інтерпретацію симптомів, вважаємо за необхідне нагадати основні аспекти клінічного перебігу перитоніту, що буде корисним для лікарів багатьох спеціальностей.

Клінічна картина перитоніту залежить від його причини та джерела, а також тривалості захворювання. Оскільки перебіг перитоніту та результат лікування багато в чому залежать від вчасності встановленого діагнозу та проведеного хірургічного втручання, варто розглянути ранні симптоми цього захворювання.

У своєму розвитку перитоніт проходить 3 стадії залежно від часу виникнення захворювання та патофізіологічних змін в організмі: реактивна - перші 24 год, токсична - 24-72 год, термінальна ->72 год.

Тяжкість стану хворих з гострим перитонітом залежить від вираженості синдрому ендогенної інтоксикації. В його розвитку важливу роль відіграють такі патологічні процеси: інтоксикація, порушення водно-електролітного, білкового та інших видів обміну речовин, порушення тканинного дихання та розвиток гіпоксії, розлади мікроциркуляції, імунодепресія.

Основний симптом перитоніту - біль у животі, який може бути різного характеру та інтенсивності: різкий «кинджальний» біль характерний для перфорації порожнистого органу, повільнонаростаючий - для запальних та деструктивних процесів в певному органі. Локалізація болю також залежить від того, в якому саме органі виникли деструктивні процеси. У міру прогресування перитоніту біль набуває поширеного характеру, приєднуються нудота та блювання, ознаки парезу кишечнику затримка відходження газів та стулу, наслідком чого $є$ здуття живота. Відмічається болючість під час ректального дослідження. На пізніх стадіях перитоніту у хворих з'являється «обличчя Гіппократа». 
Живіт відстає або не бере участі в акті дихання, у хворого може бути вимушене положення тіла. При пальпації відзначаються позитивні симптоми подразнення очеревини - напруження м'язів передньої черевної стінки та симптом Щоткіна Блюмберга, які на ранній стадії, як і біль, більше зосереджені в ділянці ураженого органа. 3 прогресуванням перитоніту симптоми з боку черевної порожнини поширюються по всіх їі відділах.

Звертають на себе увагу сухість та обкладеність язика, спрага, тахікардія, зниження артеріального тиску, підвищення температури тіла і відставання її від пульсу. При перитоніті змінюється характер дихання: відмічаються тахіпное, реберний тип дихання, живіт не бере участі в акті дихання. При локалізації процесу в малому тазі у пацієнтів відмічаються дизуричні явища, позиви до дефекації.

У загальному аналізі крові - анемія, лейкоцитоз, зсув лейкоцитарної формули вліво, підвищення швидкості осідання еритроцитів. У сечі з'являються білок, циліндри.

Характерною рисою перитоніту $\epsilon$ зміни на електрокардіограмі, особливо в токсичній і термінальній стадіях. Прогресування перитоніту веде до поліорганної недостатності, основне місце в якій посідає порушення роботи серцево-судинної системи [12].

Знаючи ці основні симптоми перитоніту, лікар зможе запідозрити чи встановити правильний діагноз і терміново направити хворого для подальшого лікування у хірургічний стаціонар.

У дослідження включено 265 хворих на перитоніт різного генезу, що проліковані в 2020 р. в хірургічному відділенні Броварської багатопрофільної клінічної лікарні, серед них 124 (46,8\%) жінки та 141 (53,2\%) чоловік.

Структура захворювань, що стали причиною перитоніту, наступна: гострий апендицит - 177 (66,8\%), гострий холецистит 32 (12,1\%), перфоративна виразка шлунка або дванадцятипалої кишки - 23 (8,7\%), гострий деструктивний панкреатит - 6 $(2,2 \%)$, перфорація пухлини - 4 (1,5\%), перфорація тонкої кишки - 5 (1,9\%), травми черевної порожнини - 11 (4,2\%), дивертикулярна хвороба ободової кишки з перфорацією - 6 (2,2\%), тромбоз мезентеріальних судин - 1 (0,4\%) випадок.

\section{Результати}

На сучасному етапі розвитку медицини $є$ великі можливості в наданні кваліфікованої допомоги хворим хірургічного профілю, але їі результати залежать від своєчасності. Для встановлення причин підвищення захворюваності на перитоніт за останні роки ми вивчили терміни госпіталізації хворих із гострими захворюваннями органів черевної порожнини.

Терміни госпіталізації пацієнтів від початку захворювання представлені в табл. 1.

Таблиця 1 Терміни госпіталізації пацієнтів

\begin{tabular}{lccccccc}
\hline \multirow{2}{*}{$\begin{array}{c}\text { Кількість пацієнтів } \\
\text { (n=265) }\end{array}$} & \multicolumn{6}{c}{ Термін госпіталізації, год } \\
\cline { 2 - 8 } & $\mathbf{5 6}$ & $\mathbf{7 - 1 2}$ & $\mathbf{1 3 - 2 4}$ & $\mathbf{2 5 - 4 8}$ & $\mathbf{4 9 - 7 2}$ & $\mathbf{7 3 - 9 6}$ & $>\mathbf{9 6}$ \\
\hline Абсолютний показник & 41 & 53 & 84 & 34 & 25 & 9 & 19 \\
\hline$\%$ & 15,5 & 20,0 & 31,7 & 12,8 & 9,4 & 3,4 & 7,2 \\
\hline
\end{tabular}

Так, найбільше пацієнтів $(31,7 \%)$ госпіталізовано в період 13-24 год з моменту розвитку захворювання. За 1-шу добу, тобто $<24$ год від початку захворювання в хірургічне відділення, госпіталізовано $178(67,2 \%)$ пацієнтів 3 перитонітом. Також варто відмітити, що досить значна частина хворих $(7,2 \%)$ зверталися за медичною допомогою через $>4$ доби після перших симптомів гострого захворювання органів черевної порожнини.

За перших 6 год 3 моменту захворювання найбільше пацієнтів госпіталізовано з гострим апендицитом - 17 (41,5\%) хворих. Також у значної частини пацієнтів діагностовані перфоративна виразка шлунка чи дванадцятипалої кишки та травми черевної порожнини - 11 (26,8\%) та 9 (22,0\%) хворих відповідно.

У період <24 год від початку захворювання госпіталізовано 131 пацієнта з гострим апендицитом, який став причиною пери- тоніту, що становило 73,6\% серед усіх госпіталізованих з перитонітом за 1-шу добу захворювання.

Серед госпіталізованих пацієнтів з перитонітом апендикулярного генезу левова частка госпіталізацій $(40,1 \%)$ припала на період 13-24 год від початку захворювання.

Показовим $\epsilon$ той факт, що у більшості пацієнтів (57,9\%), які звернулися за медичною допомогою через $>4$ доби від початку захворювання, перитоніт був спричинений гострим деструктивним холециститом.

Більшість пацієнтів (47,8\%) з перитонітом, викликаним перфоративною виразкою шлунка чи дванадцятипалої кишки, госпіталізовано до 6 год $з$ моменту захворювання. Пацієнти з перитонітом, викликаним перфорацією пухлини, рівномірно розподілилися за терміном госпіталізації: по 1 (25,0\%) хворому в період 13-24, 25-48, 49-72 та >96 год від появи перших симптомів захворювання. Половина пацієнтів $(50,0 \%)$ з перитонітом, викликаним гострим деструктивним панкреатитом, госпіталізовані в 1-шу добу від початку захворювання. Значну частину пацієнтів (40,0\%) 3 перфорацією тонкої кишки, що ускладнилася розвитком перитоніту, госпіталізували у період до 6 год від перших проявів симптомів захворювання. Травми черевної порожнини різного генезу, що викликали перитоніт, стали причиною госпіталізації більшості пацієнтів $(81,8 \%)$ в перші 6 год захворювання. Пацієнт з гострим тромбозом мезентеріальних судин госпіталізований в 1-шу добу захворювання. Лише 33,3\% пацієнтів з дивертикулярною хворобою ободової кишки, яка ускладнилася перфорацією та перитонітом, госпіталізували протягом 1-ї доби від початку захворювання.

Варто розглянути структуру перитоніту за поширеністю процесу залежно від терміну госпіталізації (табл. 2).

Таблиця 2 Структура перитоніту за поширеністю процесу залежно від терміну госпіталізації

\begin{tabular}{lccccccccc}
\hline $\begin{array}{c}\text { Поширеність } \\
\text { процесу }\end{array}$ & \multicolumn{7}{c}{ Кількість випадків, год } \\
\cline { 2 - 10 } & Всього & $\mathbf{5 6}$ & $\mathbf{7 - 1 2}$ & $\mathbf{1 3 - 2 4}$ & $\mathbf{2 5 - 4 8}$ & $\mathbf{4 9 - 7 2}$ & $\mathbf{7 3 - 9 6}$ & $\mathbf{9 9 6}$ \\
\hline Місцевий & 144 & 14 & 35 & 46 & 16 & 13 & 6 & 14 \\
\hline Дифузний & 78 & 7 & 12 & 31 & 13 & 9 & 3 & 3 \\
\hline Розлитий & 29 & 13 & 4 & 5 & 3 & 3 & - & 1 \\
\hline Загальний & 14 & 7 & 2 & 2 & 2 & - & - & 1 \\
\hline
\end{tabular}

Як показано на табл. 2, з місцевим перитонітом за 1-шу добу 3 моменту виникнення симптомів захворювання госпіталізовано 95 (66,0\%) пацієнтів, а 49 (34,0\%) - після 24 год. 3 дифузним перитонітом рання госпіталізація відбулася у 50 (64,1\%), пізня у $28(35,9 \%)$ пацієнтів. $22(75,9 \%)$ пацієнти з розлитим перитонітом госпіталізовані в перші 24 год з моменту захворювання, у $7(24,1 \%)$ вона була пізньою. Із загальним перитонітом в 1-шу добу захворювання госпіталізовано 11 (78,6\%), після 24 год - 3 $(21,4 \%)$ пацієнти.

Наведемо структуру перитоніту за характером ексудату залежно від терміну госпіталізації (табл. 3).

Таблиця 3 Структура перитоніту за характером ексудату залежно від терміну госпіталізації

\begin{tabular}{lcccccccc}
\hline \multirow{2}{*}{ Характер ексудату Кількість випадків, год } \\
\cline { 2 - 10 } & Всього & $\mathbf{5 6}$ & $\mathbf{7 - 1 2}$ & $\mathbf{1 3 - 2 4}$ & $\mathbf{2 5 - 4 8}$ & $\mathbf{4 9 - 7 2}$ & $\mathbf{7 3 - 9 6}$ & $>\mathbf{9 6}$ \\
\hline Серозний & 75 & 12 & 28 & 23 & 3 & 2 & 1 & 6 \\
\hline Серозно-фібринозний & 57 & 8 & 9 & 21 & 12 & 6 & 1 & - \\
\hline Фібринозно-гнійний & 37 & 5 & 7 & 14 & 2 & 6 & - & 3 \\
\hline Гнійний & 76 & 5 & 9 & 23 & 15 & 10 & 7 & 7 \\
\hline Каловий & 3 & 1 & - & 1 & 1 & - & - & - \\
\hline Геморагічний & 15 & 10 & - & 2 & 1 & - & - & 2 \\
\hline Жовчний & & - & - & - & - & 1 & - & 1 \\
\hline
\end{tabular}

Отже, з серозним перитонітом протягом 1-ї доби госпіталізовано 63 (84,0\%) пацієнти, а пізня госпіталізація відмічена у $12(16,0 \%)$ пацієнтів. Із серозно-фібринозним перитонітом 38 $(66,7 \%)$ пацієнтів госпіталізовано протягом 24 год 3 моменту виникнення симптомів та 19 (33,3\%) - після 24 год. Пацієнти 
3 фібринозно-гнійним перитонітом розподілилися наступним чином: 26 (70,3\%) з них госпіталізовані в 1-шу добу від початку захворювання та 11 (29,7\%) - після 24 год. 3 гнійним перитонітом 37 (48,7\%) пацієнтів госпіталізовані протягом перших 24 год 3 моменту захворювання, у 39 (51,3\%) госпіталізація була пізньою. Більшість пацієнтів (12-80,0\%) з геморагічним перитонітом госпіталізовані протягом 1-ї доби, і тільки у 3 (20,0\%) відбулася пізня госпіталізація. 3 жовчним перитонітом всі пацієнти госпіталізовані після 24 год з моменту виникнення перших симптомів.

\section{Обговорення}

Пізньою госпіталізацією хворих з перитонітом вважали госпіталізацію у хірургічне відділення пізніше 24 год з моменту виникнення захворювання. У нашому дослідженні 87 (32,8\%) пацієнтів госпіталізовано після 24 год захворювання. Аналізуючи випадки пізньої госпіталізації хворих з гострою хірургічною патологією органів черевної порожнини, яка ускладнилася перитонітом, ми виявили, що основною ії̈ причиною $\epsilon$ пізнє звернення хворих за медичною допомогою (табл. 4). Наші дані зіставні з даними інших дослідників, які займаються вивченням проблеми перитоніту [6].

Таблиця 4 Причини пізньої госпіталізації хворих із перитонітом

\begin{tabular}{|c|c|c|}
\hline \multirow{2}{*}{ Причина пізньої госпіталізації } & \multicolumn{2}{|c|}{ Кількість випадків, n=87 } \\
\hline & Абсолютний показник & $\%$ \\
\hline \multicolumn{3}{|c|}{ Догоспітальний етап } \\
\hline Самолікування & 64 & 73,6 \\
\hline Нетрадиційна медицина & 7 & 8,0 \\
\hline Помилки медичних працівників & 8 & 9,2 \\
\hline \multicolumn{3}{|c|}{ Госпітальний етап } \\
\hline Помилки хірургів & 3 & 3,5 \\
\hline Помилки лікарів інших спеціальностей & 5 & 5,7 \\
\hline Bcboro & 87 & 100 \\
\hline
\end{tabular}

На догоспітальному етапі найбільша кількість випадків пізньої госпіталізації хворих припадає на самолікування (73,6\%). За даними О.О. Біляєвої [5], в період 1992-1997 рр. самолікування було причиною пізнього звернення хворих за медичною допомогою в 21,9-28,9\% випадків. Причинами такого значного збільшення частки випадків самолікування на сьогодні, очевидно, $\in$ розвиток інтернету, доступність ліків без рецептів та велика кількість аптек.

До діагностичних помилок на догоспітальному етапі не включені випадки направлення хворого в стаціонар з помилковим діагнозом гострого захворювання органів черевної порожнини, яке натомість забезпечило своєчасну госпіталізацію.

На госпітальному етапі відмічені помилки як хірургів, так і лікарів суміжних спеціальностей (терапевт, гінеколог, уролог). У помилки хірурга включено і неповне обстеження пацієнта: невчасне виконання рентгенографії органів черевної порожнини, лапароцентезу, комп'ютерної томографії.

Протягом 1-ї доби з моменту захворювання госпіталізовано $178(67,2 \%)$ пацієнтів із перитонітом. Серед них у $95(53,4 \%)$ виявлено місцевий, у 50 (28,1\%) - дифузний, у 22 (12,3\%) - розлитий та в 11 (6,2\%) - загальний перитоніт. За характером ексудату в черевній порожнині структура перитоніту в 1-шу добу була наступною: серозний - в $63(35,4 \%)$, серозно-фібринозний в 38 (21,4\%), фібринозно-гнійний - в $26(14,6 \%)$, гнійний - в 37 $(20,8 \%)$, каловий — в $2(1,1 \%)$ та геморагічний — в $12(6,7 \%)$ випадках.

Після 24 год 3 моменту виникнення перших симптомів захворювання госпіталізували 87 (32,8\%) пацієнтів. 3 них у 49 (56,3\%) випадках відмічено місцевий, у 28 (32,2\%) - дифузний, в $7(8,0 \%)$ - розлитий, і у 3 (3,5\%) - загальний перитоніт. При пізній госпіталізації пацієнтів характер ексудату в черевній порожнині при перитоніті був серозним в 12 (13,8\%), серознофібринозним - в 19 (21,8\%), фібринозно-гнійним — в 11 (12,6\%), гнійним - в 39 (44,8\%), каловим - в 1 (1,2\%), геморагічним в $3(3,5 \%)$ та жовчним - в 2 (2,3\%) випадках.

3 вищезазначеного можна дійти висновку, що від терміну госпіталізації залежить характер ексудату. Протягом перших 24 год переважають серозні форми перитоніту. Пізніше значно зростає кількість гнійних перитонітів. Такої самої думки дотримуються й інші дослідники [13].

Функціональні зміни серцево-судинної системи у хворих на перитоніт залежать від його стадії. Тільки у 19,3\% хворих з перитонітом була нормальною електрокардіограма. У цих пацієнтів відмічали реактивну стадію перитоніту. У токсичній і термінальній стадії нормальної електрокардіограми не зафіксовано. У 84,3\% хворих виявлено тахікардію. Гіпоксія міокарда відмічена у 75,8\% хворих з термінальною стадією перитоніту [12].

\section{ВиснОВКИ}

1. Найважливіша причина незадовільних результатів діагностики та лікування перитоніту - пізнє звернення за медичною допомогою, яке $\epsilon$ наслідком самолікування чи звертання до спеціалістів нетрадиційної медицини. Із 87 випадків пізньої госпіталізації пацієнтів з перитонітом у 64 (73,6\%) випадках причиною було самолікування, у 7 (8,0\%) - використання засобів нетрадиційної медицини, в 16 (18,4\%) - помилки медичних працівників як на догоспітальному, так і на госпітальному етапах.

2. Причина великої кількості випадків самолікування, очевидно, пов'язана з розвитком інтернету, доступністю ліків без рецептів та великою кількістю аптек.

3. Серед різноманіття причин виникнення та прогресування перитоніту основну роль відіграє тривалість гострого хірургічного захворювання органів черевної порожнини, а результати лікування перитоніту, викликаного цим захворюванням, залежать від точності діагностики, своєчасності госпіталізації та проведення адекватного хірургічного втручання з ефективною інтенсивною терапією.

\section{Фінансування}

Дослідження профінансоване коштом авторів.

\section{Інформація про внесок кожного учасника}

О.О. Біляєва - розробка концепції дослідження, визначення змісту та редагування статті; В.В. Крижевський - редагування статті; І.В. Кароль - збір матеріалу, написання статті.

\section{Конфлікт інтересів}

Автори декларують відсутність конфлікту інтересів щодо цього рукопису.

\section{Згода на публікацію}

Всі автори дали згоду на публікацію цього рукопису.

\section{Список використаної літератури/References:}

1. Lenik R.H., Savytskyi I.V. et al. (2019) Doslidzhennia dynamiky leikotsytarnoho ta erytrotsytarnoho indeksiv intoksykatsii v patohenezi eksperymentalnoho perytonitu. Ukr. Zhurn. Med. Biol. Sport., 4(5): 57-61. doi: 10.26693/jmbs04.05.057. [In Ukr.].

2. Kumar S., Kumar S., Kumar S., Gautam S. (2015) Spontaneous gallbladder perforation in a patient of situs inversus totalis, misdiagnosed as perforation peritonitis due to gas under the right dome of the diaphragm. BMJ Case Rep.: 1-3. doi: 10.1136/bcr-2014-208003.

3. Kim T., Hong S.I., Park S.Y. et al. (2016) Clinical Features and Outcomes of Spontaneous Bacterial Peritonitis Caused by Streptococcus pneumoniae: A Matched Case-Control Study. Medicine (Baltimore), 95(22): e3796. doi: 10.1097/MD.0000000000003796.

4. Dzyubanovskyi I.Ya., Vervega B.M., Pidruchna S.R., Melnyk N.A. (2018) Osoblyvosti stanu prooksydantnoyi systemy pry eksperymentalnomu perytoniti na tli czukrovogo diabetu. Med. Klin. Khim., 20(4): 66-71. doi: 10.11603/mcch.2410-681X.2018.v0.i4.9799. [In Ukr.].

5. Beljaeva 0.A. (1999) Kompleksnoe lechenie peritonita i profilaktika ego oslozhnenij (jeksperimental'no-klinicheskoe issledovanie). Kiev, 375 p. [In Rus.].

6. Duzhyi I.D., Kravets O.V., Piatykop H.I. et al. (2013) Dynamika kliniko-laboratornykh pokaznykiv endohennoi intoksykatsii u khvorykh z poshyrenym perytonitom. Aktualni problemy suchasnoi medytsyny: Visn. Ukr. Med. Stomat. Akad., 13(1): 93-95. [ln Ukr.].

7. Pavlovskyi M.P. (2003) Rol i mistse mininvazyvnykh tekhnolohii u likuvanni perytonitu ta yoho septychnykh uskladnen. Klin. Khir., 4-5: 29. [In Ukr.].

8. Tomnyuk N.D., Danilina E.P., Chernyih A.N. et al. (2010) Peritonit, kak odna iz osnovnyih prichin letalnyih ishodov. Sovremennyie naukoemkie tehnologii, 10: 81-84. [In Rus.]. 
9. Sergienko V.I., Petrosyan E.A., Tereshchenko 0.A. et al. (2012) Endotelialnaya disfunkciya i metody ee korrekcii pri eksperimentalnom zhelchnom peritonite. Khirurgiya. Zhurnal im. N.I. Pirogova, 3: 54-58. [In Rus.].

10. Hrynchuk A.F. (2017) Dyferentsiina diahnostyka hostroi patolohii u nevidkladnii abdominalnii khirurhii. Klinichna anatomiia ta operatyvna khirurhiia, 16(3):29-31. D01: 10.24061/17270847.16.3.2017.75. [In Ukr.].

11. Moore L.J., Todd S.R. (2017) Common Problems in Acute Care Surgery. Springer Int. Publ., 507 p.

12. Biliaieva 0.0., Karol I.V. (2020) Dos lidzhennia zmin funktsionalnoho stanu sertsevo-sudynnoi systemy u khvorykh iz perytonitom. Klinichna khirurhiia, 87(11-12): 23-27. DOI: 10.26779/2522-1396.2020.11-12.23. [In Ukr.].

13. Zdzitovetskiy D.E., Borisov R.N. (2012) Analiz chastotyi raspostranYonnogo peritonita i rezultatov ego lecheniya v mnogoprofilnom statsionare. Sovremennyie problemyi nauki i obrazovaniya. [ln Rus.].

\section{Causes of unsatisfactory results of diagnostics of peritonitis at the prehospital stage}

\section{O.O. Bilyayeva', V.V. Kryzhevsky', I.V. Karol ${ }^{1,2}$}

${ }^{1}$ Shupyk National University of Health of Ukraine, Kyiv, Ukraine ${ }^{2}$ Brovary Multidisciplinary Clinical Hospital, Brovary, Ukraine
Abstract. The aim was study of the causes of unsatisfactory results of peritonitis diagnostics at the prehospital stage. Matherials and methods. The study included 265 patients with peritonitis of various origins, who were treated in 2020 in the surgical department of Brovary Multidisciplinary Clinical Hospital, among them there were 124 (46.8\%) females and 141 (53.2\%) males. Results. After 24 hours from the onset of the first symptoms of the disease, 87 (32.8\%) patients were hospitalized. Of these, in 49 (56.3\%) cases there was local, in 28 (32.2\%) diffuse, in 7 (8.0\%) patients - diffuse, and in 3 (3.5\%) cases - general peritonitis. At late hospitalization of patients the character of exudate in an abdominal cavity at peritonitis was serous in $12(13.8 \%)$, serous-fibrinous - in 19 (21.8\%), fibrinous-purulent — in 11 (12.6\%), purulent — in 39 (44.8\%), fecal - in $1(1.2 \%)$, hemorrhagic — in 3 (3.5\%) and bile - in 2 (2.3\%) cases. Conclusions. The most important reason for unsatisfactory results of diagnosis and treatment of peritonitis is late treatment, which is a consequence of self-medication or referral to specialists in alternative medicine. Of the 87 cases of late hospitalization of patients with peritonitis in 64 (73.6\%) cases the cause was self-medication, in $7(8.0 \%)$ - alternative medicine, in 16 $(18.4 \%)$ - errors of nurses as in prehospital, and in the hospital stages.

Key words: peritonitis, endogenous intoxication, multiorgan failure.

\author{
Відомості про авторів: \\ Біляєва Ольга Олександрівна — доктор медичних наук, професор кафедри загальної та невідкладної \\ хірургії Національного університету охорони здоров'я України імені П.Л. Шупика, Київ, Україна. ORCID \\ ID: 0000-0003-2862-0423 \\ Крижевський Вадим Віталійович — доктор медичних наук, професор, завідувач кафедри загальної \\ та невідкладної хірургії Національного університету охорони здоров'я України імені П.Л. Шупика, \\ Київ, Україна. ORCID ID: 0000-0002-8538-2583 \\ Кароль Іван Вікторович — кандидат медичних наук, асистент кафедри загальної та невідкладної \\ хірургії Національного університету охорони здоров'я України імені П.Л. Шупика (Київ, Україна), \\ лікар-хірург, лікар хірург-онколог комунального некомерційного підприємства «Броварська \\ багатопрофільна клінічна лікарня» (Бровари, Україна). ORCID ID: 0000-0003-3684-0127 \\ Адреса для кореспонденції: \\ Біляєва Ольга Олександрівна \\ 03680, Київ, просп. Любомира Гузара, 3 \\ E-mail: pr.bilyayeva@gmail.com
}

\section{Information about the authors:}

Bilyayeva Olga 0. - MD, Dr. Sc., Full Professor, Shupyk National University of Health of Ukraine, Department of General and Emergency Surgery, Kyiv, Ukraine. ORCID ID: 0000-0003-2862-0423

Kryzhevsky Vadim V. — Head, MD, Dr. Sc., Full Professor, Shupyk National University of Health of Ukraine, Department of General and Emergency Surgery, Kyiv, Ukraine. ORCID ID: 0000-0002-8538-2583

Karol Ivan V. — PhD, Shupyk National University of Health of Ukraine, Department of General and Emergency Surgery (Kyiv, Ukraine), surgeon, surgeon-oncologist of Brovary Multidisciplinary Clinical Hospital (Brovary, Ukraine). ORCID ID: 0000-00033684-0127

\section{Address for correspondence:}

Olga Bilyayeva

03680, Kyiv, L. Guzar Ave, 3

E-mail: pr.bilyayeva@gmail.com 